\title{
FIRST RECORD OF THE BAT Mimon crenulatum (E. GEOFFROY, 1801) (MAMMALIA: CHIROPTERA) IN THE STATE OF RIO DE JANEIRO, SOUTHEASTERN BRAZIL
}

\author{
MELLO, M. A. R. ${ }^{1}$ and POL, A. ${ }^{2}$ \\ ${ }^{1}$ Programa de Pós-Graduação em Ecologia, Instituto de Biologia, Universidade Estadual de Campinas, \\ CEP 13083-970, Cidade Universitária, Campinas, SP, Brazil \\ ${ }^{2}$ Laboratório de Mastozoologia, Instituto de Biologia, Universidade Federal Rural do Rio de Janeiro \\ Correspondence to: Marco Aurelio Ribeiro Mello, Departamento de Zoologia, Instituto de Biologia, \\ Universidade Estadual de Campinas, CEP 13083-970, Cidade Universitária, \\ Campinas, SP, Brazil, e-mail: marmello@gmail.com
}

Received March 24, 2004 - Accepted July 6, 2004 - Distributed February 28, 2006

(With 1 figure)

\begin{abstract}
The present study reports an extension of the geographic range of the phyllostomid bat Mimon crenulatum. This is the first record of this species in the state of Rio de Janeiro, Southeastern Brazil. Bats were captured in two conservation units of the Atlantic Forest. Data on the ecology and morphometry of the individuals are presented and compared with data recorded for other localities. The occurrence of this bat species in the region, though new, is consistent with information on its natural history found in the literature.
\end{abstract}

Keywords: Mimon crenulatum, endangered species, geographic range, Atlantic Forest, Rio de Janeiro.

\section{RESUMO}

\section{Primeiro registro do morcego Mimon crenulatum (E. Geoffroy, 1801) (Mammalia: Chiroptera) para o Estado do Rio de Janeiro, Sudeste do Brasil}

O presente estudo relata uma extensão da distribuição geográfica do morcego filostomídeo Mimon crenulatum. Este é o primeiro registro desta espécie para o Estado do Rio de Janeiro, Sudeste do Brasil. Os morcegos foram capturados em duas unidades de conservação de Mata Atlântica de baixada. Dados sobre ecologia e morfometria são apresentados, e comparados a dados registrados para outras localidades. A ocorrência desta espécie de morcego na região, apesar de nova, é consistente com informações sobre sua história natural presentes na literatura.

Palavras-chave: Mimon crenulatum, espécies ameaçadas, distribuição geográfica, Mata Atlântica, Rio de Janeiro.

\section{INTRODUCTION}

The geographic range of the bat Mimon crenulatum (E. Geoffroy, 1801) includes Southern Mexico, the Guianas, Ecuador, Peru, Bolivia, Brazil and Trinidad (Koopman, 1993). In Brazilian territory, its occurrence is listed in a few records in the Northern, Northeastern and Southeastern regions (Pedro et al., 1994). During recent fieldwork, conducted between November 1997 and
September 2001, seven specimens of $M$. crenulatum were collected. These records expanded this species' range to the South, and also provided some information on its little known natural history.

\section{MATERIAL AND METHODS}

Bats were captured in two Atlantic Forest areas in the state of Rio de Janeiro, Brazil: the Reserva Biológica Poço das Antas (Poço das Antas 
Biological Reserve, RBPA - S $22^{\circ} 30^{\prime}-22^{\circ} 33^{\prime}$, W $42^{\circ} 15^{\prime}-42^{\circ} 19^{\prime}-$ municipality of Silva Jardim) and the Fazenda do Rio Vermelho (Rio Vermelho Farm, FRV - S 22 $2^{\circ} 42^{\prime} 30^{\prime}-42^{\circ} 34^{\prime} 05^{\prime \prime} \mathrm{W}$ municipality of Rio Bonito) (Fig. 1).

Both areas, which comprise mainly lowland and submontane Atlantic Forest, contain different kinds of habitats - such as swamps and open areas (locally known as "capoeiras"), and the region is characterized as a mosaic of habitats (Scarano, 2002; Souza et al., 2000). The climate of this region is uniformly wet and hot, being classified as Am according to Koeppen's system (Takizawa, 1995). The RBPA covers about 6,100 ha, while the FRV covers about 2,000 ha. The RBPA was extensively studied for some years; the inventory of its bat fauna is given in Baptista \& Mello (2001), and data on the ecology of other bat species may be found in Mello \& Fernandez (2000) and Mello et al. (2004).

Bats were captured monthly on three consecutive nights from January 1998 to September 2001, using six standard mist-nets $(7 \times 3 \mathrm{~m})$ set at ground level or two meters above it, along trails, over ponds and streams, near fruiting and flowering plants and near other attractive sites. Data on sex, age, reproductive condition, and body measurements (weight, and tibia and forearm length) were recorded. Individuals were considered adults on the basis of their degree of ossification of the wing's phalangeal epiphyses (following Kunz, 1988). The reproductive condition was estimated on the basis of external characters, such as abdomen and nipple condition for females, and testis position for males.

Voucher specimens were killed using sulfuric ether; later they were fixed using formaldehyde solution (10\%), and preserved in ethylic alcohol solution $(70 \%)$. These specimens are stored in the Adriano Lúcio Peracchi Chiroptera Collection at the Universidade Federal Rural do Rio de Janeiro. External and skull measurements were taken following the protocol proposed by Pedro et al. (1994) in order to allow for comparisons. Due to the small sampling size, males and females were analyzed together. Body weight was measured with a Pesola spring scale (1 g accuracy).

\section{RESULTS}

In the Poço das Antas Biological Reserve, six individuals of $M$. crenulatum were separately

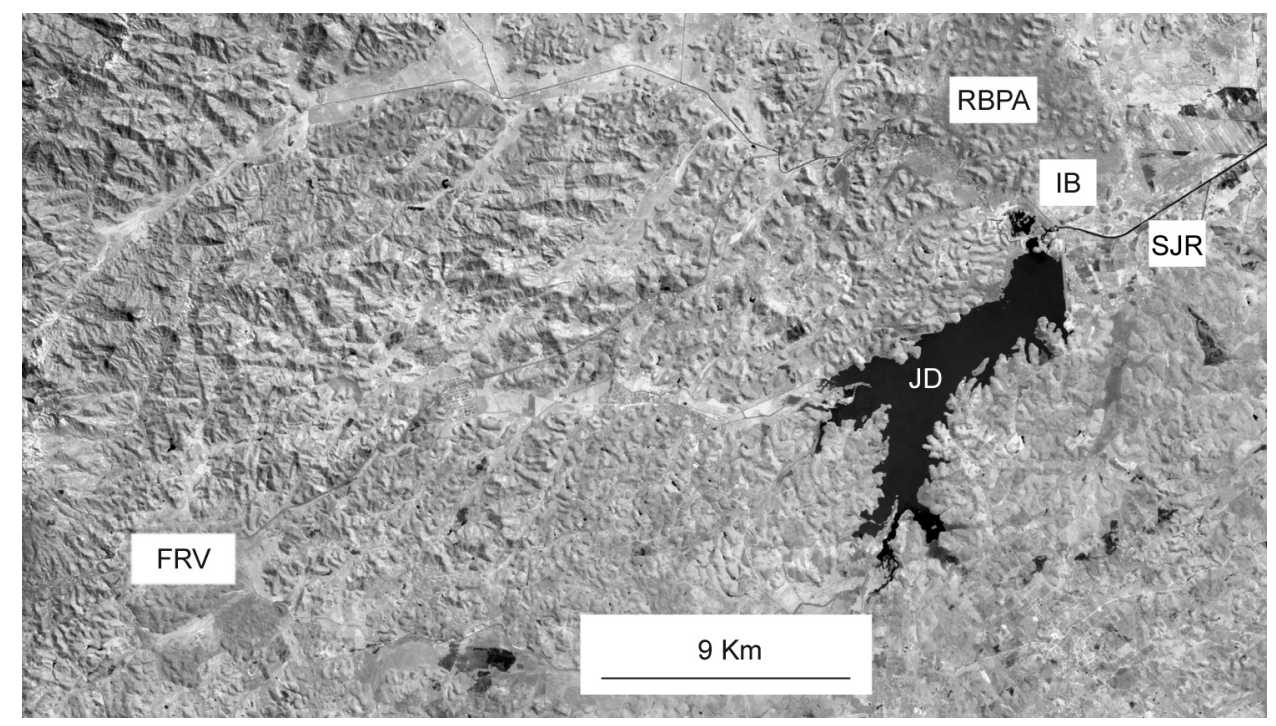

Fig. 1 - Satellite image of the region where the two study areas are located, Fazenda Rio Vermelho (FRV) and Reserva Biológica Poço das Antas (RBPA), including the area of the Ilhas dos Barbados (IB), the Juturnaíba Dam (JD) and the São João River (SJR). Dark gray patches are forests, black patches are water, straight lines are roads, and other lighter grayish patches are open vegetation. Clinton Jenkins (University of Tennessee) provided us the Landsat 7 ETM+ image (bands 4, 5 and 6). 
sampled in December 1998, January 1999, February 1999, March 1999, October 1999, and January 2000. On the other hand, on Rio Vermelho Farm, only one specimen was sampled in January 2000 over the Rio Vermelho river. M. crenulatum accounted for $0.3 \%$ of the total of 2,596 captures during the monthly four-year study in the RBPA (Mello, 2002).

Except for one individual sampled at a fourmeter height, all the specimens were captured at ground level, near water (swamps or rivers). All the individuals were captured before $19 \mathrm{~h} 30$ except for one female captured at $23 \mathrm{~h}$ at RBPA. Only two fecal samples of the bats were obtained, and both contained only unidentifiable insect fragments.

In the present study two juveniles (a male and a female) were captured in January 1999 and January 2000, respectively, and a post-lactating female was captured in December 1999. All the captured males appeared to be reproductively inactive in February, March, and October 1999, and January 2000.

Cranial measurements $(\mathrm{mm})$ were taken from captured specimens and were compared with data found in the literature. The values are presented as "mean (minimum-maximum) sample size": forearm length $=52.27(50.10-53.70) 7$; longest skull length $=23.62(23.30-23.80) 4$; condylobasal length $=21.22(21.10-21.40) 4$; length of maxillary toothrow $=8.53(8.45-8.60) 4$; length of mandibular toothrow $=9.32(9.20-9.50) 4$; breadth across upper molars $=9.15(9.00-9.20) 4$; postorbital constriction $=4.52(4.40-4.80) 4 ;$ zygomatic breadth $=13.19(12.90-13.70) 4$; breadth of braincase $=9.00(8.80-9.40) 4$; breadth across mastoid processes $=12.51(12.20-12.80) 4$; and weight $=18.0(14.0-24.0) 7$.

\section{DISCUSSION}

The available data suggest that $M$. crenulatum prefers the understory (Bernard, 2001; Simmons \& Voss, 1998), but there are few studies on vertical stratification of bat communities in the Neotropics (e.g., Bernard, 2001; Handley, 1967; Kalko, 1998). This species is frequently found in damp places such as rivers, ponds and waterholes, and our findigs are consistent with this pattern (Handley, 1976; Pedro et al., 1994). However, M. crenulatum has also been sampled in dry forest environments
(Pedro et al., 1994; Simmons \& Voss, 1998), in the Brazilian semi-arid biome of the Caatinga (Willig, 1983), and in a Brazilian amazonian savannah (Bernard \& Fenton, 2003).

As for its activity, the pattern of higher frequency at dusk has also been reported in other studies (Pedro et al., 1994; Bernard, 2001; Simmons \& Voss, 1998), and may be related to its mainly insectivorous diet, as in the case of molossids and vespertilionids, for instance (Pedro et al., 1994).

Most studies indicate that $M$. crenulatum feeds mainly on insects (Pedro et al., 1994; Bernard, 2001; Simmons \& Voss, 1998), but it can also consume small vertebrates, pollen and nectar (Pedro et al., 1994). Our study is consistent with the insectivore feeding habit, which was confirmed by the analysis of fecal samples of $M$. crenulatum composed only of insect fragments (unfortunately unidentifiable).

In Central Amazonia, Bernard \& Fenton (2003) observed that two M. crenulatum individuals used areas of 65 and 78 ha, and flew maximum linear distances of 0.5 and $1.0 \mathrm{Km}$, suggesting a pattern of activity not restricted to the vicinity of their day roosts. These two individuals also flew over open savanna areas, suggesting that the matrix environment of our study area may not be a barrier for dispersal. They also found that M. crenulatum displayed strong roost fidelity, sleeping in the same hollow tree for 16 consecutive nights. Therefore, we may consider that the bats captured in the present study could be residents of the area.

There is a lack of information on the reproductive pattern of $M$. crenulatum. Pedro et al. (1994) suggested that breeding starts at the beginning of the rainy season in Southeastern Brazil. Although our data pool may be insufficient to allow for safe inferences and comparisons, we suggest that the pattern at our study site is similar.

Descriptions and measurements of M. crenulatum are available in many publications; we consulted those given in Handley (1960), Goodwin \& Greenhall (1961), Husson (1962), Pedro et al. (1994) and Simmons \& Voss (1998). Koopman (1993) recognized five subspecies for M. crenulatum, and these specimens found in the state of Rio de Janeiro closely match previous descriptions of M. c. picatum (Handley, 1960; Pedro et al., 1994). The measurements are slightly higher than those obtained for specimens from the 
Brazilian municipalities of Uberlândia in the state of Minas Gerais (Pedro et al., 1994) and Lamarão in the state of Bahia (Carter \& Dolan, 1978), which are referred to as M. c. picatum (Pedro et al., 1994).

The low relative abundance of $M$. crenulatum found in the present study $(0.3 \%)$ and in the literature suggests that it can be considered a rare species in the bat community throughout its range. Other papers have reported the following relative abundances: Pedro et al. (1994) in Uberlândia (Brazil) reported a value of $5 / 233=2 \%$; Brosset et al. (1996) in French Guiana, 35/8,031 = 0.4\%; Bernard(2001) nearManaus (Brazil), 9/936 $=0.9 \%$; Kalko \& Handley (2001) in Belém (Brazil), $3 / 1,871=0.1 \%$; and Schultze et al. (2000) in Guatemala, $1 / 901=0.1 \%$. In Southeastern Brazil, a few specimens of $M$. crenulatum have been documented from only three localities: Três Marias (18 12' 24" S-45 14 ' 31' W) (Mares et al., 1989); and Uberlândia ( $\left.18^{\circ} 55^{\prime} 08^{\prime \prime} \mathrm{S}-48^{\circ} 16^{\prime} 39^{\prime \prime} \mathrm{W}\right)$ in the state of Minas Gerais (Pedro et al., 1994), and Linhares (19 23' 29" S-40 04' 21' $\mathrm{W})$ in the state of Espírito Santo (Peracchi \& Albuquerque, 1993).

In the state of Rio de Janeiro, the occurrence of $M$. crenulatum had been previously reported by Esbérard (1998), and again by Bergallo et al. (2000), on the basis of a single specimen collected in the Grajaú Forest Reserve $\left(22^{\circ} 55^{\prime} 31^{\prime \prime} \mathrm{S}\right.$ $43^{\circ} 16^{\prime} 04^{\prime}$ 'W), a Conservation unit located inside the urban area of Rio de Janeiro.

Before the present report was written, the above-mentioned specimen, which was kindly yielded for our analysis, had been identified as another member of the Phyllostominae subfamily (Phyllostomus discolor - identified by André Pol), which proves that prior records of this species in the state were erroneous. The present record is really the first for the state of Rio de Janeiro, which seems to represent the southernmost record for M. crenulatum in Brazilian territory.

Acknowledgments - We would like to thank Adriano L. Peracchi and Marcelo R. Nogueira (UFRRJ) for assisting us in the species' identification. We are indebted to our colleagues who helped us with fieldwork and data analysis, especially Gilberto M. Schittini, Igor França, Jorge L. Nascimento, Jacqueline M. Gomes, Leonardo C. Oliveira, Marcia Baptista, and Pedro Selig, and Fernando A. S. Fernandez for advising MARM in the early phase of the project, and for loaning us the field vehicle. We acknowledge IBAMA (Brazilian Institute for the Environment and Renewable Resources) for granting us a research license for Poço das Antas and for providing valuable information on the reserve. We are also very grateful to our sponsors: FAPERJ, CAPES, Lincoln Park Zoo Neotropic Fund, PROBIO (PRONABIO-MMA, supported by BIRD/GEF), and CNPq/PIBIC/UFRJ.

\section{REFERENCES}

BAPTISTA, M. \& MELLO, M. A. R., 2001, Preliminary inventory of the bat species of the Poço das Antas Biological Reserve, RJ. Chiroptera Neotropical, 7(1): 133-135.

BERGALlO, H. G., ROCHA, C. F. D., ALVES, M. A. S. \& VAN SLUYS, M., 2000, A Fauna Ameaçada de Extinção do Estado do Rio de Janeiro. EdUERJ, Rio de Janeiro.

BERNARD, E., 2001, Vertical stratification of bat communities in primary forests of Central Amazon, Brazil. Journal of Tropical Ecology, 17: 115-126.

BERNARD, E. \& FENTON, M. B., 2003, Bat Mobility and Roosts in a Fragmented Landscape in Central Amazonia, Brazil. Biotropica, 35(2): 262-277.

BRosset, A., CHARLES-DOMINIQUE, P., COCKLE, A., COSSON, J. F. \& MASSON, D., 1996, Bat communities and deforestation in French Guiana. Canadian Journal of Zoology, 74: 1974-1982.

CARTER, D. C. \& DOLAN, P. G., 1978, Catalogue o the type specimens of Neotropical bats in selected European museums. Special Publications Texas Tech University, 15: 1-136.

ESBÉRARD, C. E. L., 1998, Validade dos parâmetros da IUCN em amostra regional - Há espécies de morcegos ameaçadas no município do Rio de Janeiro? Boletim da Fundação $O$ Boticário de Proteção à Natureza, XXV.

GOODWIN, G. G. \& GREENHALL, A. M., 1961, A review of the bats of Trinidad and Tobago. Bull. Amer. Mus. Nat. Hist., 122: 187-302.

HANDLEY, C. O., 1960, Descriptions of new bats from Panama. Proc. U. S. Natl. Mus., 112: 459-479.

HANDLEY, C. O., 1967, Bats of the canopy of an Amazonian Forest. Atlas do Simpósio sobre a Biota Amazônica, 5: 211-215.

HANDLEY, C. O., 1976, Mammals of the Smithsonian Venezuelan Project. Brigham Young Univ. Sci. Bull. - Biol. Ser., 20(5): 1-89.

HUSSON, A. M., 1962, The bats of Suriname. Zool. Verh. Rijksmus. Nat. Hist. (Leiden), 52: 1-282.

KALKO, E. K. V., 1998, Organization and diversity of tropical bat communities through space and time. Zoology, 101: 281-297.

KALKO, E. K. V. \& HANDLEY-JR., C. O., 2001, Neotropical bats in the canopy: diversity, community structure, and implications for conservation. Plant Ecology, 153: 319-333.

KOOPMAN, K. F., 1993, Chiroptera. In: D. E. Wilson \& D. M. Reeder (eds.), Mammalian species of the world. Smithsonian Institution Press, Washington.

KUNZ, T. H., 1988, Ecological and behavioral methods for the study of bats. Smithsonian Institution Press, Washington. 
MARES, M. A., BRAUN, J. K. \& GETTINGER, D., 1989, Observations on the distribution and ecology of the mammals of the Cerrado grasslands of central Brazil. Annals Carnegie Museum, 58: 1-60.

MELLO, M. A. R. \& FERNANDEZ, F. A. S., 2000, Reproductive ecology of the bat Carollia perspicillata (Chiroptera: Phyllostomidae) in a fragment of the Brazilian Atlantic Coastal forest. Zeitschrift für Säugetierkunde, 65: 340-349.

MELLO, M. A. R., 2002, Interações entre o morcego Carollia perspicillata (Linnaeus, 1758) (Chiroptera: Phyllostomidae) e plantas do gênero Piper (Linnaeus, 1737) (Piperales: Piperaceae) em uma área de Mata Atlântica. M. Sc. Dissertation (Ecology). Universidade do Estado do Rio de Janeiro, Rio de Janeiro.

MELLO, M. A. R., SCHITTINI, G., SELIG, P. \& BERGALLO, H. G., 2004, Seasonal variation in the diet of the bat Carollia perspicillata (Chiroptera: Phyllostomidae) in an Atlantic forest area in southeastern Brazil. Mammalia, 68(1): 49-55.

PEDRO, W. A., KOMENO, C. A. K. \& TADDEI, V. A., 1994, Morphometrics and biological notes on Mimon crenulatum (Chiroptera: Phyllostomidae). Boletim do Museu Paraense Emílio Goeldi, sér. Zool., 10(1): 107-112.

PERACCHI, A. L. \& ALBUQUERQUE, S. T., 1993, Quirópteros do município de Linhares, Estado do Espírito
Santo, Brasil (Mammalia: Chiroptera). Revista Brasileira de Biologia, 53(4): 575-581.

SCARANO, F. R., 2002, Structure, function and floristic relationships of plant communities in stressful habitats marginal to the Brazilian Atlantic Rainforest. Annals of Botany, 90: 517-524.

SCHUlTZE, M. D., SEAVY, N. E. \& WHITACRE, D. F., 2000, A comparison of the phyllostomid bat assemblages in undisturbed Neotropical forest and in forest fragments of a slash-and-burn farming mosaic in Peten, Guatemala. Biotropica, 32(1): 174-184.

SIMMONS, N. B. \& VOSS, R. S., 1998, The mammals of Paracou, French Guiana: a Neotropical lowland rainforest fauna - Part 1: Bats. Bulletin of the American Museum of Natural History, 237.

SOUZA, A. F., MARTINS, F. R. \& MATOS, D. M. S., 2000, Detecting ontogenetic stages of the palm Attalea humilis in fragments of the Brazilian Atlantic forest. Canadian Journal of Botany, 78: 1227-1237.

TAKIZAWA, F., 1995, Levantamento pedológico e zoneamento ambiental da Reserva Biológica de Poço das Antas. Monografia de Bacharelado. Escola Superior de Agricultura Luis de Queiros - Universidade de São Paulo, Piracicaba.

WILLIG, M. R., 1983, Composition, microgeographic variation, and sexual dimorphism in caatingas and cerrado bat communities from northeast Brazil. Bull. Carnegie Mus. Nat. Hist., 23: 1-131. 